\title{
STOCK REPURCHASE ABUSES AND THE NO PREJUDICE RULE*
}

CORPORATE reacquisition of shares may seriously threaten the interests of creditors and remaining stockholders. ${ }^{1}$ Because of this danger, many states have a general rule permitting repurchase only if these interests are not prejudiced. ${ }^{2}$ Strict application of this "no prejudice" rule has adequately safeguarded creditors. ${ }^{3}$ But the remaining stockholders receive scant protection, since courts usually will invoke the rule on their behalf only when stock repurchase flagrantly violates their interests, ${ }^{4}$ or presents some danger to the general public. ${ }^{5}$

A shareholder seeking the repurchase of his stock usually falls into one of two broad classes-classes widely differing in the merits of the claim they present. He may be an outsider who was originally induced to invest on

right, like the right to work, Truax v. Raich, 239 U.S. 33 (1915), or the right to own and enjoy property, Shelley v. Kraemer, 334 U.S. 1 (1948), or, as in the Valle case, the right to make and enforce a contract.

*Winchell v. Plywood Corporation, 85 N.E.2d 313 (Mfass. 1949).

1. This Note is concerned only with some of the perennial abuses of stock repurchases. Reacquisition of stock by a corporation may, of course, be occasioned by legitimate and desirable goals. Illustrative of these are: reduction of stock issued in excess of charter, enforcement of a lien or foreclosure of chattel mortgage secured by the corporation's stock, and implementation of employee stock purchase plans. For an excellent general discussion of these and other legitimate uses of the repurchase power see Nemmers, The Poricr of a Corporation to Purchase its Oann Stock, [1942] Wrs. L. Rev. 161, 163.

Depending upon the specific factual situation involved, other functions of stock repurchase may be either desirable or undesirable. Adams v. Protective Union Co., 210 Mlass. 172, 96 N.E. 74 (1911) (attempts to buy out dissenting shareholders) ; Interstate Distributing Co. v. Connell, $46 \mathrm{~Pa}$. Super. 551 (1911) (acceptance of stocks in cancellation of debt).

2. The "no prejudice" rule and the other rules applicable to stock repurchase are set out, by jurisdictions, in the appendix at the end of this Note.

3. See, e.g., In re Feckheimer Fishel Co., 212 Fed. 357 (2d Cir. 1914); In re Vulean Soot Cleaner Co., 11 F. Supp. 388 (W.D. Pa. 1935).

4. See Interstate Distributing Co. v. Connell, $46 \mathrm{~Pa}$. Super. 551 (1911) (repurchase contract after start of liquidation to give stockholder par value for his stock held unenforceable though agreed to by liquidating trustee); Augsburg Land \& Improvement Co. v. Pepper, 95 Va. 92, 27 S.E. 807 (1897) (repurchase contract made after stockholder attended meeting where it was agreed to liquidate held unenforceable).

5. Thus, where more than one-third of the outstanding stock of a large power company had been sold with the representations that it would be repurchased at par on demand, the position of other stockholders seeking to enjoin the enforcement of the repurchase contracts as prejudicial was manifestly strengthened by threats of disruption of vital public services and losses to creditors. Hoops v. Leddy, 119 N.J. Eq. 296, 182 Atl. 271 (Ch. 1936). Comparison of this case with a previous one, dealing with the same corporation and repurchase contracts, indicates the persuasive weight of the public interest factor. In the carlier case, Downs v. Jersey Central Power \& Light Co., 115 N.J. Eq. 348, 170 Atl. 835 (Ch. 1934), aff'd., 117 N.J. Eq. 138, 174 Atl. 887 (Ct. Err. \& App. 1934), the large amount of stoel affected was not known, and the New Jersey court had no difficulty in arriving at a contrary result. 
the strength of a repurchase contract; or he may be an insider trading on an influential position. Sales inducement contracts made with an outsider may benefit the original stockholders because this is often the only way the corporation can attract needed capital. Having bargained for and received money plasma in time of corporate stress, the original stockholders should not later be allowed to reject the contract terms. Repurchases from an insider, on the other hand, whether resulting from prior executory contract or spontaneous transaction, frequently give undue advantage to a dominant stockholder or director at the expense of the best interests of the corporation. Consequently, when later attacked by the other shareholders, insider transactions of this kind seldom merit the same favorable judicial recognition as outsider transactions.

Courts have recognized this fundamental difference. Ignoring the no prejudice rule in cases arising from executory repurchase contracts made with outsiders, ${ }^{6}$ the courts in effect have utilized the rule only in transactions involving influential shareholders. Even in insider cases, however, the rule is grudgingly applied.

Winchell v. Plywood Corporation ${ }^{7}$ typifies the minimal safeguard the rulo affords other stockholders. Plaintiff Winchell was a stockholder, director and treasurer of the corporation when in 1938 the corporation, represented solely by its President, ${ }^{8}$ contracted to repurchase his stock at his option. Few stockholders ${ }^{9}$ were aware of this agreement until 1945 when, just one hour before he voted for liquidation, Winchell demanded performance. ${ }^{10}$ If enforced, the contract would have given Winchell approximately $\$ 20,000$ more than he would have received as a liquidating stockholder. ${ }^{11}$ The court: held the agreement not prejudicial on the ground that "fairness of the contract with respect to the rights of other stockholders must be tested by the circumstances existing at the time it was made." 12

The fairness test applied by the court rests on the familiar freedom of contract notion that a contracting party always knows his own best interest. ${ }^{13}$ But whatever the validity of this reasoning in ordinary commercial

6. See, e.g., Griffin v. Bankers' Realty Investment Co., 105 Neb. 419, 181 N.W. 169 (1920); Grace Securities Corp. v. Roberts, 158 Va. 792, 164 S.E. 700 (1932).

7. 85 N.E.2d 313 (Mass. 1949).

8. Id. at 315. Apparently the agreement was subsequently approved by the corporation's three directors, only one of whom, Winchell, was still a stockholder or director at the time repurchase was demanded. Id. at 316. Approval by the directors apparently consisted of mere year-end ratification of all action taken by the officers during the year.

9. At the time Winchell sought repurchase of his shares there were five stockholders in the corporation, including Winchell. Three of these shareholders testified without contradiction that they were unaware of the repurchase contract until Winchell demanded its performance on May 24, 1945. Record, pp. 77, 80, 107.

10. Record, pp. 81, 124. Winchell, of course, was aware of the plan to sell the assets prior to the liquidation meeting. 85 N.E.2d 313,315 .

11. This was Winchell's own estimate. Record, p. 26.

12. 85 N.E. $2 d$ d $313,318$.

13. Ibid. 
transactions, it has little applicability to the Wincliell case, where the stockholder-complainants had no knowledge of the contract at the time it was made. The no prejudice rule was devised to protect stockholders- who in repurchase cases are the real parties in interest-and it perverts the rule to assume that notice to the corporation is notice to them.

The excessive price which Winchell received for his stock is but one of the many abuses to which insider repurchases are subject. Influential stockholders may also be permitted to withdraw painlessily from shaky corporations ${ }^{14}$ or to receive valuable assets for stock of doubtful worth. ${ }^{15}$ Repurchases can also be used to manipulate control of the corporation, for as long as the repurchased stock remains unsold, the voting power of outstanding stock will be proportionately increased. ${ }^{10}$ Finally, repurchase may be used to avoid payment of legitimate dividends. ${ }^{17}$

In all of these instances, the rights of the many stockholders are prejudiced to benefit the few. Courts, however, usually do not so find. ${ }^{18}$ On the theory that the stock taken back is commensurate in value to the repurchase price, they frequently declare that such repurchases do not reduce capital, ${ }^{10}$

14. Thus in Barrett v. Webster Lumber Co., 275 Mfass. 302, 175 N.E 765 (1931), the corporation's general manager who had purchased common stocl: for $\$ 35,887.50$ was permitted to have his shares repurchased by the corporation at a time when its assets were less than its liabilities, and when it was unable to pay its current liabilities as they became due. Moreover, he was given an excessive price for this stock-six notes in the total amount of $\$ 43,023.28$. Cf. Murphy v. Hanlon, 322 MIass. 683, 79 N.E.2d 292 (1948).

15. See, e.g., Dupee v. Boston Water Power Co., 114 1Fass. 37 (1873) (stoclaholders purchasing corporate land permitted to pay one half the sale price in over-valued corporate stock). An unsuccessful attempt to barter dubious stock for corporate land is presented in Augsburg Land \& Improvement Co. v. Pepper, 95 Va. 92, 27 S.E. 807 (1897).

16. E.g., Gilchrist v. Highfield, 140 Wis. 476, 123 N.W. 102 (1909). In the Gilehrist case, more than one half of a corporation's stock was held in a partnership agreement by two stockholders. One shareholder-partner desired to sell out. The other purchased part of his shares with money borrowed from the corporation and caused the remainder of the shares to be repurchased by the corporation, thereby retaining effective control. Cf. Spiegcl v. Beacon Participations, Inc., 297 Mfass. 398, 8 N.E.2d 895 (1937), where control was retained within an interlocking directorate group by use of the repurchase power.

17. In Gilchrist v. Highfield, supra note 16 , only two dividends had been paid in the 10 years prior to repurchase of the stock-for which accumulated surplus was expended over the vain protests of the minority stockholders.

18. Thus in Missachusetts, where such suits appear to be most common, and where the requirement that repurchase be without prejudice to other stockholders is continually reiterated with approval, there seems to be no reported case in which a repurehase has been invalidated as prejudicial to the other stockholders. See, however, note 4 supra.

In contrast, the courts usually will not tolerate inequitable attempts by controlling stockholders to enforce corporate option repurchase agreements against a single shareholder, thus forcing return of his shares to the corporation. E.g., Albert E. Touchet, Inc. v. Touchet, 264 Mass. 499, 163 N.E. 184 (1928) ; Adams v. Protective Union Co., 210 Mass. 172, 96 N.E. 74 (1911).

19. E.g., Barrett v. Webster Lumber Co., 275 1fass. 302, 175 N.E. 765 (1931).

The theory that repurchased shares are a corporate asset has been thuroughly demolished by the commentators. See, e.g., Ballantrine, Conronations $\$ \$ 2563,260$ (rev. ed. 1946). 
even though in fact the stock may not be marketable at all because of generally declining business conditions or the pinched straits of the particular corporation. ${ }^{20}$ And often the courts offer the rationale that the repurchases fall within the area of permissible business discretion. ${ }^{21}$

Shareholders could be adequately protected against these insider trading abuses if the courts would rigorously apply the no prejudice rule to transactions of this kind, and recognize injury to stockholders who in fact have been harmed. ${ }^{22}$ In no case involving an insider transaction should the finding on the question of prejudice be altered by the existence or non-existence of a prior executory contract. And in all insider cases in which a prior executory contract has been made without the knowledge of the remaining shareholders, fairness of the transaction should be tested as of the time performance is demanded. ${ }^{23}$ Otherwise, repurchase contracts with buyer's option allow the insider to choose the time of repurchase most favorable to himself-a time which will be correspondingly prejudicial to the other stockholders.

Repurchases based on sales inducement contracts present a different case. Innocent and commercially unknowing buyers are frequently led to make purchases on the strength of corporate contracts to repurchase at the buyer's option. ${ }^{24}$ Efforts to enforce these contracts, even when they result from the

20. The notion that repurchase does not reduce the corporate assets is actually an unconvincing myth with which the courts are wont to salve their consciences. See Nemmers, The Power of a Corporation to Purchase its Ozen Stock, [1942] Wis. L. Rev. 161, 167.

21. Spiegel v. Beacon Participations, Inc., 297 Mass. 398, 431, 8 N.E.2d 895, 914 (1937), indicates a typical "hands-off" attitude: "The circumstance that it was in the minds of the defendant directors that control of the defendant might remain in the hands of the bank and its successor does not vitiate their conduct not harmful in other particulars.

"No provision of law required the directors, in making these purchases of stock . . . to buy them ratably from the stockholders." Accord, Murphy v. Hanlon, 322 Mass. 683, 79 N.E.2d 292 (1948).

22. See the excellent dissenting opinion of Timlin, J. in Gilchrist v. Highfield, 140 Wis. $476,478,123$ N.W. 102, 103 (1909).

Failure to apply effectively the no prejudice requirement has resulted in its displacement in many jurisdictions by various types of statutory regulations more rigid than the "majority rule," see appendix, infra. The issue no longer is whether or not stock repurchase is to be permitted-only New Hampshire and Utah affirmatively prohibit such action. Instead, the main conflict now concerns the most desirable and effective means of policing the reptrchase power. But see Nussbaum, Acquisition by a Corporation of its Ozu Stock, 35 Cot. L. REv. 971, 978 (1935) (well-documented argument for prohibition of repurchase).

23. Creditors are now accorded a comparable interpretation of the no prejudice rule. See In re Feckheimer Fishel Co., 212 Fed. 357 (2d Cir. 1914). See, also, Robinson v. Wangemann, 75 F.2d 756 (5th Cir. 1935) (creditors protected from subsequently arising prejudice when notes taken for repurchased stock fell due 10 years later).

24. E.g., Porter v. Plymouth Gold Mining Co., 29 Mont. 347, 74 Pac. 938 (1904) (dificulty in selling stock in speculative enterprise surmounted by offering it on a six-month option to return; repurchase contract valid. But $c f$. Americanized Finance Corp. v. Yarbrough, 223 Ala. 266, 135 So. 448 (1931) (opposite result, ostensibly on grounds of insufficient tender). 
unauthorized action of corporate agents, ${ }^{25}$ have been almost uniformly successful $;^{26}$ the no prejudice rule, virtually non-existent in the insider cases, is completely ignored when the court is confronted with the meritorious claim of an unwary buyer. ${ }^{27}$

In paying their respects to the superior equitable position of outside buyers, however, the courts ignore the equally worthy claims of stockholders who were without knowledge of the transaction. When the stockholders have assented to sale of stock tied to a repurchase contract, ${ }^{29}$ the no prejudice rule manifestly should be held inapplicable. But where, as frequently happens, the contract is a result of unauthorized action by stock salesmen, stockholders without notice seem as worthy of protection as the unwary buyer. While in these circumstances losses to original stockholders might be rationalized as a risk incident to pursuit of profit, the practical impossibility of restraining commission-compensated corporate agents from making unauthorized repurchase representations makes this risk a heavy burden.

Aware of the competing equitable interests which sales inducement contracts create and the difficulty of reaching a judicial solution fair to all parties, ${ }^{29}$ several states prohibit use of repurchase contracts for sales purposes. $^{30}$ But a blanket prohibition of this kind also prevents use of repur-

25. See Stratbucker v. Bankers Realty Investment Co., 107 Neb. 194, 185 N.W. 271 (1921) ; Grace Securities Corp. v. Roberts, 158 Va. 792, 164 S.E. 700 (1932). See, also, Wisconsin Lumber Co. v. Greene and Western Tel. Co., 127 Iowa 350, 101 N.W. 742 (1904).

26. E.g., Davies v. MIontana Auto Finance Corp., 86 XIont. 500, 284 Pac. 267 (1930) (court speaks in usual terms of retention of contract benefits by corporation, constructive ratification by corporation, corporation's being estopped to deny authority to so contract); Kennerly v. Columbia Chemical Corp., 137 Va. 240, 119 S.E. 265 (1923) (protection given to a gullible purchaser who had been persuaded to take $\$ 15,000$ worth of stock in return for his farm with the understanding that the corporation would repurchase $\$ 10,000$ worth of the stock at buyer's option, if exercised within one year).

27. Generally in such cases prejudice to other stockholders is not even mentioned. E.g., Kennerly v. Columbia Chemical Corp., stipra note 26. See also note 6 supra.

Actually, it is at times difficult to tell from the decisions to just what extent the holder of a sales inducement repurchase contract was an unwary buyer. The courts then rest enforcement of the agreement on the broader ground of benefit to the corporation. See Davies v. Miontana Auto Finance Corp., supra note 26.

28. Acquiesence by the stockholders may actually be explicit, or it may be implied from a provision in the corporate charter authorizing this type of repurchase.

29. See Epes, J., dissenting in Grace Securities Corp. v. Roberts, 158 Va. 792, 806, 164 S.E. 700, 705 (1932).

30. See Classification VI, appendix, infra. In the jurisdictions set out in Classification VI, where repurchase is permitted only for specific purposes, provisions for sales inducement repurchases are conspicuously absent. Two states prohibit stock repurchases entirely. See Classification II, appendix, infra. It should be noted however, that these statutes apparently permit buyer's option redemptive right preferred stock, the issue of which may equally prejudice other stockholders.

Ballantine indicates that preferred stock which must be redeemed at the holder's option does not in reality constitute a true contribution of capital; rather that it is in essence a contingent liability. Ballatitrne, Corporatrons $\$ 218$ (rev. ed. 1946).

For discussion of salient problems in reference to redemptive right stosk, see Dodd, 
chase agreements even when formally authorized by the corporation, and thus eliminates what may at times be a desirable and necessary means of corporate finance.

A preferable statute would permit repurchase agreements but would condition their validity upon formal incorporation of the contract in the stock certificate. It would also require shares not subject to repurchase to be identified as such on the certificate. A statute of this kind would preclude only unauthorized contracts, and thus would single out and effectively eliminate the real source of prejudice to other stockholders in sales inducement transactions. ${ }^{31}$ Conversely, the statute would put all prospec. tive buyers on notice that only formal corporate commitments would be enforceable.

\section{APPENDIX}

The "majority rule" and the various other rules concerning stock repurchase are set out below in tabular form to show the prevalence and distribution of each rule. Minor variations are not indicated in the chart.

$\begin{array}{ll}\text { Nule } & \text { No. of } \\ \text { States }\end{array}$

I. The "majority rule": re- 13 purchase permitted in the absence of statutory or selfimposed restrictions if in good faith and without prejudice to creditors or other stockholders.
II. The "minority rule": re- 2 purchase prohibited.

\section{Jurisdiction}

Americanized Finance Corp. v. Yarbrough, 223 Ala. 266, 135 So. 448 (1931); Copper Belte Mining Co. v. Costello, 11 Ariz. 334, 95 Pac. 94 (1908); Fitzpatrick v. McGregor, 133 Ga. 332, 65 S.E. 859 (1909); Tierncy v. Butler, 144 lowa 553, 123 N.W. 213 (1909); Bates Street Shirt Co. v. Waite, 130 Mc. 352 156 Atl. 293 (1931); Winchell v. Plywood Corp., 85 N.E.2d 313 (Mass. 1949); Davies v. Montana Auto Finance Corp., 86 Mont. 500, 284 Pac. 267 (1929); Hoops v. Leddy, 119 N.J. Eq. 296, 182 Atl. 271 (Ch. 1936); Byrd v. Tidewater Power Co., 205 N.C. 589, 172 S.E. 183 (1934); West Texas Utillties Co. v. Ellis, 133 Tex. 104, 126 S.W.2d 13 (1939); Marshall v. Fredricksburg Lumber Co., 162 Va. 136, 173 S.E. 553 (1934); Farmers' Bank v. Champlain Transp. Co., 3 Washb. 131 (Vt. 1846); Gilchrist v. Highfield, 140 Wis. 476, 123 N.W. 102 (1909).

Latullipe v. New England Inv. Co., 77 N.H. 31, 86 Atl. 361 (1913); Pace v. Pace Bros. Co., 91 Utah 132, 59 P.2d 1 (1936).

Purchase and Redemption by a Corporation of its Onen Shares: The Substantive Lane, 89 U. of PA. L. REv. 697, 719 (1941) (excellent extensive history of general repurchase power).

31. A further protection might be afforded the other stockholders by providing that the directors be prohibited from authorizing sales inducement repurchase agrcements unless given such power by the corporate charter. Such provision would at least afford all stockholders an opportunity to determine if the corporation could engage in this type of financing. Under the existing no prejudice rule, non-prejudicial repurchase is permitted in the absence of specific statutory or self-imposed restriction. See Classification I, appendix, infra. 